\title{
Claudia Lage - O corpo interminável
}

Rio de Janeiro: Record, 2019

\author{
Carlos Wender Sousa Silva*
}

Claudia Lage lançou, no final de novembro de 2019, mais um romance que remete à ditadura militar brasileira. É mais uma obra pós-Comissão da Verdade (INSTITUTO VLADIMIR HERZOG, 2014) com essa temática. Mas não se trata apenas de mais uma narrativa literária sobre a ditadura. É um romance fundamental para os nossos dias. É uma resposta às diferentes violências advindas de instituições e de representantes públicos e também dos espaços privados. É mais uma resposta necessária ao autoritarismo que tenta novamente fincar suas raízes na realidade brasileira. É essencialmente uma obra literária que apresenta as relações humanas como potência de vida, de resistência e de liberdade.

A autora desse romance é escritora e roteirista, escreveu e foi coautora de telenovela premiada, com diferentes trabalhos importantes na televisão. Sua produção literária também já é consolidada. Estreou com o conto $A$ hora do galo, ocasião em que escritores como Sérgio Sant'Anna a conheceram. Em 2000, lançou o livro A pequena morte e outras naturezas, que reúne 13 contos que abordam temas como amor, morte e as relações humanas em geral como espaços para se estabelecer encontros e possibilitar trocas.

Em 2009, lançou Mundos de Eufrásia, obra em que recria a personagem histórica Eufrásia Teixeira Leite, que se relacionou com Joaquim Nabuco, importante abolicionista do século XIX. Já nesse romance, notamos uma produção literária que busca entrelaçar ficção e realidade narrativa literária e fatos históricos. Mundos de Eufrásia é um romance que discute aspectos da emancipação feminina e da igualdade de gênero, com elementos referentes à época e aos nossos dias. Lage foi finalista no Prêmio São Paulo de Literatura de 2010 por essa obra, na categoria Autor Estreante. Em 2013, publicou Labirinto da palavra.

O romance $O$ corpo interminável traz alguns elementos que parecem permear a produção literária de Claudia Lage. Nessa obra, ela trabalha a aproximação entre ficção - imaginário - e realidade, pensa a escrita como um processo reflexivo e de amadurecimento dentro da própria narrativa literária, destaca a discussão em torno de um determinado recorte político-histórico da realidade brasileira - tortura, repressão e violências praticadas pelo regime ditatorial - e, ainda, coloca o corpo, sobretudo o corpo feminino, como o expoente de todos esses movimentos históricos, políticos, sociais e psicológicos.

$\mathrm{Na}$ narrativa, somos guiados através da relação que os personagens Daniel e Melina estabelecem. Daniel é filho de uma guerrilheira desaparecida. Melina, por sua vez, questiona-se de forma recorrente sobre o passado dos pais e, pouco a pouco, vai revelando a indiferença e a conveniência deles em relação àquele contexto histórico e político ditatorial. A leitura do romance nos leva até o encontro e a união entre os dois personagens. Ambos se conhecem ao compartilharem a leitura de um mesmo livro em uma biblioteca. Do lado de Daniel, o silêncio do avô levou o jovem a imaginar a morte da mãe de diferentes formas desde pequeno. Em determinado trecho do livro, ele relembra um desenho feito na escola, ainda criança, que havia levado a professora a comunicar ao avô - o mesmo avô que se silencia a respeito da mãe do neto. D. Jandira, a vizinha, é quem o ajuda com o neto.

Os segredos entre os dois adultos, os móveis no lugar, o quarto da mãe, as caixas de papelão guardadas há anos no armário do avô, todos esses elementos constroem o imaginário de Daniel. Um livro incompleto, encontrado na estante do avô, chama sua atenção. Um menino que se vê diante da narrativa de Alice, a fantasia, o imaginário e, também, diante da realidade, a narrativa da mãe, uma desaparecida política. Após a morte do avô, Daniel tem até mesmo dificuldade de doar os móveis,

*Universidade de Brasília, Brasília, DF, Brasil. (Dorcid.org/0000-0001-8955-4023. E-mail: sousasilvabr@gmail.com 
pois tudo aquilo está vinculado a uma história, carrega uma energia, vestígios de uma história interrompida e de outra que precisa seguir. Assim se apresenta um narrador que busca alguma resposta para além da escrita, nas rugas, nas cavidades, na própria passagem do tempo.

Nesse sentido, essa narrativa literária é construída a partir de vestígios daquela história. A própria literatura reconstrói uma identidade por meio de fragmentos da memória e do esquecimento, de elementos ficcionais e reais. Daniel encontra uma irmã, Olívia, filhos do mesmo pai, José Antônio Guimarães. Olívia revela a Daniel a história dos avós e do pai. Há aí uma contradição entre o velho e novo. O novo aparece como possibilidade de restauração, como potência, transformação, ressignificação da humanidade e de um passado interrompido.

Melina, em contrapartida, também divide com Daniel sua história. Ela demonstra gosto por fotografias, sobretudo o interesse em fotografar a caneca suja de leite depois do café da manhã e a expressão facial da mãe. Melina faz associações sobre sua família; partindo do presente, em que está localizada, procura nos pais e na casa algum elemento. Ela então vai ao passado - nos registros escritos, nas fotografias, nas histórias - e retorna ao presente na tentativa de compreendê-lo. O pai de Melina, contratado como fotógrafo, demonstra a indiferença desse homem em relação aos crimes da ditadura. O certificado de curso de fotografia do Exército, o nome do pai de Melina como aluno, as fotos tiradas após o óbito das vítimas da ditadura, em decorrência de sessões de tortura e de violência, um fotógrafo responsável por fazer esses registros. Tudo são indícios, indicam qualquer participação ou consentimento.

Em meio à relação de Daniel e Melina, as histórias de várias mulheres são reveladas. Uma mulher grávida e um homem que escolhe deixar o escritório para viver com ela. Sua realidade transformada pelo fato de se tornar mãe e de ter que se dividir com o desejo de transformar sua realidade, lutar contra o Estado de exceção instaurado. Uma mãe que deixa o bebê com os sogros para ser interrogada e, consequentemente, torturada e violentada. Uma mulher que, na prisão, conhece outra prisioneira, penteia seus cabelos e estabelece um vínculo afetivo. Todas essas relações apontam para corpos que se constroem em relação a outros corpos.

Um elemento importante dessa narrativa literária é a intersecção entre a ficção e a realidade, ou seja, a possibilidade de adentrar numa zona do imaginário e da criação e a capacidade de se posicionar e construir elementos diante da realidade apresentada. Nesse sentido, podemos pensar o processo de criação literária como um recurso artístico que transita por esses dois caminhos. A Alice do livro e a Alice da fotografia são uma transposição desse encontro. Um menino que se encontrou com a fantasia - Alice - e a realidade - a narrativa da mãe. É aqui também que surge um questionamento em torno das próprias possibilidades e limitações da representação: até que ponto tomar para si esse lugar de representar alguém nos confere certa legitimidade, e em que medida esse lugar se mantém dentro de um espaço que conforma interesses artísticos e compromisso ético. Essa reflexão é ressaltada pelo próprio narrador:

(Melina) Olhava demoradamente as páginas, como se as registrasse mentalmente. Já eu desviava logo os olhos, como se pudesse esquecê-las. Só depois, muito depois, consegui escrever. Ainda assim, me sentia como se cometesse um equívoco. Um grande equívoco. Como se forçasse aquelas pessoas, tão reais, tão vivas dentro de suas lutas, desaparecimentos e mortes, a se tornarem meras referências em um texto, ou pior, personagens, meus personagens, como se eu impusesse a elas, depois de tudo que viveram, algo tão frágil, capaz de se desmantelar ao menor sopro, à mínima insistência, uma farsa, uma representação (Lage, 2019, p. 24).

Outro aspecto que vale destacar é a atribuição à escrita o papel de ser um processo reflexivo e de amadurecimento dentro do próprio processo criativo. Um caminho traçado da leitura à escrita se revela. Todas as vivências, encontros, possibilidades, leituras, releituras são entendidos não só como processo de conhecimento, mas também de constituição do próprio eu, de um corpo, das relações desse corpo com os demais, e mesmo das rupturas e das fragmentações históricas, sociais e subjetivas. A escrita permite sair da história individual, de um personagem, e percorrer as múltiplas histórias semelhantes - de quem lutou, resistiu, de quem se silenciou, consentiu, de quem torturou, estuprou, violentou. 
O processo de escrita e as possibilidades e desdobramentos daí advindos revelam concomitantemente funções e intenções artísticas e sociais. A construção da narrativa se coloca como uma tomada de posição diante da realidade e se apresenta como abertura reflexiva e crítica na medida em que assume esse papel ou compromisso social e coletivo. A maneira como esse romance é construído evidencia alguns elementos que dizem respeito ao engajamento e à atuação pública da própria literatura. Papéis necessários, sobretudo, em tempos de crise e de ascensão de forças e movimentos reacionários e violentos.

Mesmo uma estante cheia de livros não bastaria. Estarão sempre duvidando um do outro, reafirmando as próprias crenças e questionando a verossimilhança alheia. Será sempre preciso mais livros e nunca será o suficiente. Será sempre preciso dizer mais alguma coisa e nunca será o bastante. Será sempre colocado à prova o que foi dito, e será sempre preciso dizer de novo (Lage, 2019, p. 71).

A escrita é contaminada pela realidade. Ela se apresenta como possibilidade de permanência, espaço para constituir uma memória formada a partir de fragmentos, rupturas, vestígios, coisas não ditas, vozes silenciadas, vozes manifestas, fatos passados, despercebidos, projeções criadas. O processo de leitura e compreensão desses movimentos se traduz na maneira como essa escrita é registrada, ou seja, ela é influenciada pela dinâmica e pela complexidade das relações humanas, as quais se consolidam a partir da atuação dos agentes, seus interesses, seus ideais e seus compromissos.

Antes, a celulose da madeira se usava para fazer papel, fibras de algodão extraídas de trapos e roupas velhas. Era assim que se escrevia, sobre as fibras dos farrapos, vi isso no livro sobre restauração, conto à Melina. Os panos, imersos em água e cal, se desintegravam. Com as fibras se fazia uma pasta, que era prensada e colocada para secar ao sol. Sobre essa superfície se escrevia, esse material feito de pano, suor, poeira, vestígios de gente andando nas ruas, de gente tirando e colocando as roupas, lavando e secando-as no varal, usando até desbotar as cores, até gastar o tecido, até romper os fios. Sempre há algo já existente no processo da escrita, você não acha. Escrever nunca começa do nada, de um ponto vazio, inabitado, limpo, nunca se começou, o próprio papel é outra coisa transformada. Escrevemos e tocamos nessas fibras esgarçadas, amassadas e prensadas; escrevemos e vestimos as roupas usadas, limpamos a sujeira, nos afogamos na água e secamos ao sol. Escrevemos e remexemos nos panos usados para cobrir a nudez, tirados após um dia de trabalho, arrancados para o desejo do corpo, sujos por todas as coisas que sujam, limpos por todas as coisas que limpam. Virados ao verso e ao avesso. Nos contaminamos, submergimos do melhor e do pior. Nunca estamos inocentes (Lage, 2019, p. 72-73).

Dizer que essa escrita nunca parte do zero significa dizer que ela emerge mediada pelas escritas já apresentadas, pelas leituras já realizadas, pelas relações já estabelecidas e interrompidas, pelas experiências vivenciadas, pelos sonhos imaginados, pelas frustrações, anseios, desejos, lutas, resistências e vitórias já conquistadas. Essa escrita traduz também a tentativa de silenciamento, a opressão diária, a violência habitual, o sufoco de uma realidade que muitas vezes se mostra inumana. E, embora uma palavra ou outra apareça em diferentes textos, registros e narrativas, ela nunca é a mesma palavra, pois traz naquele momento específico a potência de vida de quem a exprime e de quem ela busca dar voz. A escrita é, em última análise, uma resposta à violência e à barbárie. "Quais são as palavras certas, pergunto, o verbo certo, corrijo, talvez não seja nem mesmo uma palavra, apenas um som, um ruído, um resto de língua morta e moída, mas ainda assim é preciso, tenho certeza de que é preciso descobrir, pronunciar" (Lage, 2019, p. 98).

A tortura, a repressão e a violência ditatorial também são elementos centrais em $O$ corpo interminável. A moça que começa a rir ao testemunhar para um documentário a tortura sofrida na ditadura, fato destacado por Melina na narrativa literária, revela uma das diferentes manifestações e condutas que podem se exprimir após um evento traumático como tal. O trecho do livro em que uma personagem está em processo de parto e é torturada ao mesmo tempo atinge uma complexidade estética profunda e intensa, sem necessariamente ser sensacionalista nem tentar reduzir as dores e os traumas de quem sofreu violência semelhante àquela narrada 
no texto ficcional. Somos guiados pela riqueza da construção estética da narrativa literária de Claudia Lage e pela fidedignidade ética da autora.

A narrativa revela mecanismos utilizados pelas vítimas para ficar inconscientes durante a tortura - interrogatórios. A própria ideia de interrogatório e de tortura que são indissociáveis na ditadura é ressaltada. Os cúmplices, apoiadores e simpatizantes, todos são apontados como agentes diretos ou indiretos dentro desse sistema repressivo. Relatos sobre as prisões também aparecem na narrativa.

E, finalmente, O corpo interminável, ou seja, um corpo que se estende, que se perpetua, é apresentado como a extensão da prática humana, das relações desiguais, violentas, impostas, mas também por aquelas relações afetivas, possibilitadas por meio de trocas e da criação de laços. Há uma dissolução das fronteiras entre o corpo, o que é vivido e o que é imaginado criado. O corpo se estende através de experiências, vivências, quebras, rupturas, não ditos. Melina fala desse corpo em desequilíbrio, em metamorfose. Daniel procura projetar esses corpos por meio da escrita. Melina, através da fotografia. Esse corpo também aparece numa contradição entre o novo e o velho. Por exemplo, o corpo do pai de Melina que passa de um corpo forte e musculoso e termina numa casa de repouso, esquálido. Por outro lado, Melina, grávida, parece retomar um processo de constituição do novo, que pode emergir como possibilidade de resistência à violência. Um corpo que inicia a vida, deixando abertas pequenas frestas de luz para o futuro em meio a uma realidade decadente e limitada.

\section{Referências}

INSTITUTO VLADIMIR HERZOG (2014). Comissão Nacional da Verdade. Memórias da Ditadura. São Paulo: Instituto Vladimir Herzog. Disponível em: http://memoriasdaditadura.org.br/. Acesso em: 9 jan. 2020.

LAGE, Claudia (2019). O corpo interminável. Rio de Janeiro: Record. 